\title{
Chimeric antigen receptor-modified T cell therapy in chronic lymphocytic leukemia
}

Yixin Zou ${ }^{1,2,3}$, Wei $\mathrm{Xu}^{1,2,3}$ and Jianyong $\mathrm{Li}^{1,2,3^{*}}$ (D)

\begin{abstract}
Chronic lymphocytic leukemia (CLL), a common type of B cell chronic lymphoproliferative disorder in adults, has witnessed enormous development in its treatment in recent years. New drugs such as ibrutinib, idelalisib, and venetoclax have achieved great success in treating relapsed and refractory (R/R) CLL. In addition, with the development of immunotherapy, chimeric antigen receptor-engineered T cells (CAR-T) therapy, a novel adoptive immune treatment, has also become more and more important in treating R/R CLL. It combines the advantages of T cells and B cells via ex vivo gene transfer technology and is able to bind targets recognized by specific antibodies without antigen presentation, thus breaking the restriction of major histocompatibility complex. So far, there have been lots of studies exploring the application of CAR-T therapy in CLL. In this review, we describe the structure of chimeric antigen receptor, the preclinical, and clinical results of CAR-T therapy against CLL, along with its adverse events and advances in efficacy.
\end{abstract}

Keywords: Chimeric antigen receptor, Chronic lymphocytic leukemia, Immunotherapy, T cell, Toxicity

\section{Background}

Chronic lymphocytic leukemia (CLL) is a common type of B cell chronic lymphoproliferative disorder with varied treatment options as a result of its heterogeneity. It mainly affects the elderly, and the 5-year survival rate for CLL patients is $79.2 \%$ [1-3]. To date, it is still an incurable disease and a lot of patients, especially those with tumor protein 53 (TP53) disruption, will relapse rapidly after first-line immunochemotherapy-based treatment. Therefore, new weapons are needed. New drugs such as ibrutinib and venetoclax have achieved great success even in relapsed and refractory (R/R) CLL. Besides, the great potential of immunotherapy in CLL also has already aroused worldwide interest.

Chimeric antigen receptor-engineered T cells (CAR-T) therapy, a novel adoptive immune treatment initially invented in 1989, is now attracting more and more attention because of its promising effects even for highly refractory hematological malignancies. Through gene transfer technology, $\mathrm{T}$ cells can express chimeric antigen

\footnotetext{
*Correspondence: lijianyonglm@126.com

'Department of Hematology, The First Affiliated Hospital of Nanjing Medical University, Jiangsu Province Hospital, Nanjing 210029, China

${ }^{2}$ Key Laboratory of Hematology of Nanjing Medical University, Nanjing 210029, China

Full list of author information is available at the end of the article
}

receptor (CAR) targeting specific antigens. The advantage of CAR-T cells over conventional autologous $\mathrm{T}$ cells is that by equipping $\mathrm{T}$ cells with CAR, it can identify antigens via major histocompatibility complex independent recognition. Preclinical and clinical results show that CAR-T therapy is a feasible way to treat R/R CLL. By summarizing the recent advances, we hope to introduce in detail the application of CAR-T therapy in CLL and provide a new perspective for R/R CLL treatment.

\section{Structure of chimeric antigen receptor}

CAR comprises four important elements, including an extracellular targeting domain, a hinge or spacer, a transmembrane domain and an intracellular signaling domain $[4,5]$. Extracellular targeting domains are usually single chain variable fragments (scFv) consisting of heavy chain variable regions and light chain variable regions of immunoglobulin (Ig) [6]. A spacer/hinge, which often derives from human IgG1, IgG4, and CD8, is designed to connect $\mathrm{scFv}$ with transmembrane domain [7-9]. The length of this structure alters CAR activation and $\mathrm{scFv}$ flexibility by determining the distance between $\mathrm{scFv}$ and tumor antigen. A transmembrane motif takes auxiliary responsibility to assist $\mathrm{scFv}$ and intracellular signaling domain, and $\mathrm{CD} 3 \zeta / \mathrm{CD} 28$ are common molecules in it. 
Intracellular signaling domain is involved in CAR-T cells activation and proliferation. It is comprised of $\mathrm{CD} 3 \zeta$ or FceRI $\gamma$ and co-stimulatory signaling domains such as CD28 or CD137 [10, 11]. Up to now, there are at least four generations of CAR-T cells, and the second generation is most commonly used. First generation has a single signaling molecule, and $\mathrm{CD} 3 \zeta$ is most commonly used. Second generation can generate double signals via $\mathrm{CD} 3 \zeta$ and a co-stimulatory domain [12, 13], and third generation has two co-stimulatory molecules. Fourth generation consists of multiple types, including TRUCK T cells [14] and CAR-T with suicide genes $[15,16]$. Currently, most scFvs are murine-derived which may lead to clearance of CAR-T cells due to immunogenicity so that weakening the efficacy of the treatment. To solve this problem, CAR-T with human-derived scFv is developed and is superior to that with murine-derived scFv [17]. In addition, a new idea "universal CAR-T cells," which are derived from healthy donors, could overcome the problems of dysfunction of $\mathrm{T}$ cells in patients and make "off-the-shelf" come true by editing genes of $\mathrm{T}$ cell receptor and human leukocyte antigen [18, 19]. CAR-T cells can be directed against tumor with certain antigen. However, under most circumstances, normal cells and tumor cells share some important antigens. In consideration of safety, researchers add programmed cell death protein 1 (PD-1) and cytotoxic T-lymphocyte-associated protein 4 (CTLA-4)-based inhibitory chimeric antigen receptors (iCAR) that can bind ligands on common cells to CAR-T cells. On this occasion, if these CAR-T cells come across normal cells, they will fail to activate [20]. By contrast, some investigators construct new CAR-T cells carrying chimeric co-stimulatory receptors (CCR) recognizing antigens existed in cancer cells so that they can only be activated when binding to two antigens expressed on tumor cells at the same time [21, 22]. Target antigen loss is a common reason for the failure of CAR-T therapy, but losing two antigen at the same time is rare. As a result, CD19-CD20 bispecific CAR-T cells are designed and showed their efficacy in killing CD19-negative CLL cells [23]. In addition, switchable dual-receptor CAR-engineered $\mathrm{T}$ cells were designed in order to make CAR-T cells controllable in the aspect of activation and toxicity [24].

\section{The application of CAR-T therapy in CLL: preclinical and clinical data}

Choosing a satisfying target is a key step for CAR-T therapy. Chimeric antigen receptor can bind to a wide range of antigens that exist on the surface of cells, such as proteins, carbohydrate, ganglioside, proteoglycan, and heavily glycosylated protein [25-27]. Scientists hope to find a specific antigen only expressed on tumor cells, but this type of antigen has been difficult to come across. Other principles of a good target are that antigens are highly expressed on tumor cells and are the key elements to their function, while on normal cells their expression is weak or negative [28]. In 2009, Kochenderfer and his colleagues [29] had validated that CAR-T cells can specifically kill primary CLL cells. To date, a lot of potential antigens, such as CD19 and CD23, have been studied in preclinical and clinical research studies of CLL. Clinical trials of CAR-T therapy for patients with CLL are shown in Table 1.

\section{CD19}

CD19, a B cell surface protein, is expressed on almost all malignant B cells, normal B cells at different stages, and follicular dendritic cells, but hardly on other cells $[30,31]$. Moreover, it is vital for B cell activation. The first clinical trial for CLL was launched in 2011, evaluating the efficacy of autologous anti-CD19 CAR-T cells (CD28 as the co-stimulatory molecule) in eight $R / R$ patients. The first four patients did not receive cyclophosphamide while the next four patients did. Patients with and without cyclophosphamide preconditioning were infused with $(1.2-3.0) \times 10^{7}$ CAR-T cells $/ \mathrm{kg}$ and $(0.4-1.0) \times 10^{7}$ CAR-T cells $/ \mathrm{kg}$, respectively. Eventually, patients without cyclophosphamide-conditioning had no response to CAR-T therapy and died from disease progression, while for the four patients treated with cyclophosphamide, three exhibited stable disease (SD), and one remained progressive (PD) [32]. The toxicities mainly included grades 1-2 fever, rigors, chills, and grade 3 febrile neutropenia. One patient taking $3.2 \times 10^{9}$ CAR-T cells without cyclophosphamide suffered from grade 5 hypotension and renal failure. In other two studies, totally eight R/R CLL patients got cyclophosphamide and fludarabine followed by $(0.1-2.8) \times 10^{7}$ CAR-T cells $/ \mathrm{kg}$. Eventually, four patients achieved complete remission (CR), three partial remission (PR), and one SD [33, 34]. Grades 3 and 4 adverse events usually occurred in 8 days after CAR-T cells infusion, including hypotension, fever, acute renal failure, hypoxemia, hyperbilirubinemia, capillary leak syndrome, obtundation, liver enzymes/creatinine/electrolyte abnormalities, upper extremity thrombosis, and urinary tract infection. Besides, because of the elimination of normal B cells, some patients developed hypogammaglobulinemia. These results showed that CAR-T therapy did have the potential to control the disease resistant to chemotherapy. Compared with patients without previous lymphodepleting therapies, wonderful capacity of proliferation and persistence of CAR-T cells were seen in preconditioning patients because preconditioning might enhance the proliferation and persistence of CAR-T cells by reducing tumor burden, releasing tumor antigens, inducing inflammation, and eliminating immunosuppressive cells such as regulatory $\mathrm{T}$ cell and myeloid-derived suppressor cells 
Table 1 Open clinical trials of CAR-T-cell therapy for patients with CLL

\begin{tabular}{|c|c|c|}
\hline ClinicalTrials ID & Trial title/description & Target \\
\hline NCT02640209 & $\begin{array}{l}\text { Pilot Trial Of Autologous T Cells Engineered To Express Anti-CD19 Chimeric Antigen Receptor } \\
\text { (CART19)In Combination With Ibrutinib In Patients With Relapsed Or Refractory CD19+ } \\
\text { Chronic Lymphocytic Leukemia (CLL)Or Small Lymphocytic Lymphoma (SLL) }\end{array}$ & CD19 \\
\hline NCT02644655 & $\begin{array}{l}\text { Immunotherapy Using Autologous T Cell-Engineered With CD19-specific Chimeric Antigen } \\
\text { Receptor for the Treatment of Recurrent /Refractory B Cell Leukemia }\end{array}$ & CD19 \\
\hline NCT02456350 & $\begin{array}{l}\text { Anti-CD19 Chimeric Antigen Receptor (CAR)-Transduced T Cell Therapy for Patients With B } \\
\text { Cell Malignancies }\end{array}$ & CD19 \\
\hline NCT03076437 & $\begin{array}{l}\text { Anti-CD19 Chimeric Antigen Receptor (CAR)-Transduced T Cell Therapy for Patients With B } \\
\text { Cell Malignancies }\end{array}$ & CD19 \\
\hline NCT01865617 & $\begin{array}{l}\text { Laboratory Treated T Cells in Treating Patients With Relapsed or Refractory Chronic } \\
\text { Lymphocytic Leukemia, Non-Hodgkin Lymphoma, or Acute Lymphoblastic Leukemia }\end{array}$ & CD19 \\
\hline NCT02933775 & CD19-redirected Autologous Cells (CAR-CD19 T Cells) & CD19 \\
\hline NCT02672501 & $\begin{array}{l}\text { A Study to Assess CD19-targeted Immunotherapy T Cells in Patients With Relapsed or } \\
\text { Refractory CD19+ B Cell Leukemia }\end{array}$ & CD19 \\
\hline NCT01853631 & $\begin{array}{l}\text { Activated T-Cells Expressing 2nd or 3rd Generation CD19-Specific CAR, Advanced B-Cell NHL, } \\
\text { ALL, and CLL (SAGAN) }\end{array}$ & CD19 \\
\hline NCT03110640 & $\begin{array}{l}\text { Anti-CD19 CAR T Infusion Combined With Allogeneic Stem Cell Transplantation for B-cell } \\
\text { Leukemia/Lymphoma }\end{array}$ & CD19 \\
\hline NCT01747486 & CD19 Redirected Autologous T Cells & CD19 \\
\hline NCT03085173 & $\begin{array}{l}\text { A Trial of "Armored" CAR T Cells Targeting CD19 For Patients With Relapsed CD19+ } \\
\text { Hematologic Malignancies }\end{array}$ & CD19 \\
\hline NCT02685670 & $\begin{array}{l}\text { Competitive Transfer of \#CD19-TCRz-CD28 and \#CD19-TCRz-CD137 CAR-T Cells for B-cell } \\
\text { Leukemia/Lymphoma }\end{array}$ & CD19 \\
\hline NCT02782351 & Humanized CAR-T Therapy for Treatment of B Cell Malignancy & CD19 \\
\hline NCT00881920 & $\begin{array}{l}\text { Kappa-CD28 T Lymphocytes, Chronic Lymphocytic Leukemia, B-cell Lymphoma or Multiple } \\
\text { Myeloma, CHARKALL }\end{array}$ & Kappa \\
\hline NCT02050347 & $\begin{array}{l}\text { Activated T Lymphocytes Expressing CARs, Relapsed CD19+ Malignancies Post-Allo } \\
\text { HSCT(CARPASCIO) }\end{array}$ & CD19 \\
\hline NCT02963038 & CAR T Cells for Refractory B Cell Malignancy & CD19 \\
\hline NCT03068416 & CD19-targeting, 3rd Generation CAR T Cells for Refractory B Cells Malignancy & CD19 \\
\hline NCT03166878 & $\begin{array}{l}\text { A Study Evaluating UCART019 in Patients With Relapsed or Refractory CD19+ Leukemia } \\
\text { and Lymphoma }\end{array}$ & CD19 \\
\hline NCT03448393 & $\begin{array}{l}\text { CD19/CD22 Chimeric Antigen Receptor (CAR) T Cells in Children and Young Adults With } \\
\text { Recurrent or Refractory CD19/CD22-expressing B Cell Malignancies }\end{array}$ & CD19/CD22 \\
\hline NCT03191773 & $\begin{array}{l}\text { A Study of Anti-CD19 CAR-T Cell Immunotherapy for Refractory /Relapsed B Cell } \\
\text { Malignancies }\end{array}$ & CD19 \\
\hline NCT02132624 & $\begin{array}{l}\text { CD19-targeting 3rd Generation CAR T Cells for Refractory B Cell Malignancy - a } \\
\text { Phase I/lla Trial }\end{array}$ & CD19 \\
\hline NCT03277729 & $\begin{array}{l}\text { A Phase I/II Study to Evaluate the Safety of Cellular Immunotherapy Using Autologous T Cells } \\
\text { Engineered to Express a CD20-Specific Chimeric Antigen Receptor for Patients With Relapsed } \\
\text { or Refractory B Cell Non-Hodgkin Lymphomas }\end{array}$ & CD20 \\
\hline NCT02851589 & $\begin{array}{l}\text { Study Evaluating the Efficacy and Safety of PCAR-019 in CD19 Positive Relapsed or Refractory } \\
\text { Leukemia and Lymphoma }\end{array}$ & CD19 \\
\hline NCT02819583 & $\begin{array}{l}\text { CAR-T Cell Immunotherapy in CD19 Positive Relapsed or Refractory Leukemia and } \\
\text { Lymphoma }\end{array}$ & CD19 \\
\hline NCT03302403 & $\begin{array}{l}\text { Clinical Study of Redirected Autologous T Cells With a Chimeric Antigen Receptor in Patients } \\
\text { With Malignant Tumors }\end{array}$ & CD19 \\
\hline NCT02706392 & Genetically Modified T-Cell Therapy in Treating Patients With Advanced ROR1+ Malignancies & ROR1 \\
\hline NCT01626495 & $\begin{array}{l}\text { Phase I/IIA Study of CART19 Cells for Patients With Chemotherapy Resistant or Refractory } \\
\text { CD19+ Leukemia and Lymphoma }\end{array}$ & CD19 \\
\hline NCT01475058 & CD19 CAR T Cells for B Cell Malignancies After Allogeneic Transplant & CD19 \\
\hline NCT03331198 & Study Evaluating Safety and Efficacy of JCAR017 in Subjects With Relapsed or Refractory & CD19 \\
\hline
\end{tabular}
CLL or SLL (TRANSCEND-CLL-004) 
Table 1 Open clinical trials of CAR-T-cell therapy for patients with CLL (Continued)

\begin{tabular}{llll}
\hline ClinicalTrials ID & Trial title/description & Target \\
\hline NCT01593696 & Anti-CD19 White Blood Cells for Children and Young Adults With B Cell Leukemia or & CD19 \\
Lymphoma & Long-term Follow-up Study for Patients Previously Treated With a Juno CAR T-Cell Product & CD19 \\
NCT01864889 & Treatment of Relapsed and/or Chemotherapy Refractory B-cell Malignancy by CART19 & CD19 \\
NCT03050190 & A Phase I/II Multiple Center Trial of 4SCAR19 Cells in the Treatment of Relapsed and & CD19 \\
& Refractory B Cell Malignancies & \\
\hline
\end{tabular}

[35-37]. Additionally, CAR-T cells would be eliminated because of murine single chain variable fragment. Therefore, preconditioning was needed to suppress autoimmunity in order to slow down the clearance of CAR-T cells [17]. Furthermore, these studies revealed that, in spite of receiving lower number of CAR-T cells, patients who got cyclophosphamide and fludarabine had higher overall response rate than those with cyclophosphamide only (87.5\% vs $25.0 \%$ ), which illustrated that using fludarabine and cyclophosphamide for preconditioning was superior to cyclophosphamide alone.

CD137, also known as 4-1BB, affects the persistence of CAR-T cells. Previous reports demonstrated that CAR-T coupled with CD28 could kill tumor cells effectively in the first 7 days, and CAR-T equipped with CD137 persisted longer $[38,39]$. A comparison of CAR-T cells' signaling domain based on published data was presented in Table 2. So far, there have been three published articles assessing the values of anti-CD19-CD137-CD3ל CAR-T cells transfected with lentivirus [10, 40, 41]. A total of 14 CLL cases, including 6 TP53 deficient patients, were infused with $(0.14-11) \times 10^{8}$ CAR-T cells after chemotherapy conditioning (six with bendamustine, three with fludarabine/cyclophosphamide, and five with pentostatin/cyclophosphamide). Eventually, four patients achieved CR and four PR. Totally nine patients suffered from grades 1-4 cytokine release syndrome (CRS), and the median occurrence day was 7. Tocilizumab or glucocorticoid was used in five patients, and four patients were admitted into the intensive care unit (ICU) because of hypotension and hypoxemia. In addition, neurotoxicity was seen in five patients, and almost all patients whose CAR-T treatment was effective had $\mathrm{B}$ cell aplasia and hypogammaglobulinemia. CAR copies could be detected after 1 year in patients with CR. Therefore, CAR-T cells coupled with CD137 transfected with lentivirus also showed beneficial and persistent effects on R/R CLL, similar to those with CD28.

The function of $\mathrm{T}$ cells is usually impaired, even exhausted in CLL patients, which may restrict the capacity of CAR-T cells. Accordingly, relevant studies using allogeneic retrovirally transduced anti-CD19-CD28 $\zeta$ CAR-T cells were carried out in the past 5 years in order to explore whether using donor-derived $\mathrm{T}$ cells was a good approach to overcome this limitation. A total of nine R/R CLL subjects who relapsed after allogeneic hematopoietic stem-cell transplantation took part in clinical trials, and none of them received chemotherapy conditioning before infusing $(1.5-12) \times 10^{7} / \mathrm{m}^{2}$ or $(0.4-$ $3.1) \times 10^{6} / \mathrm{kg}$ CAR-T cells. Consequently, one patient exhibited CR, two PR, two SD, and four PD. No graft-versus-host disease occurred after infusion, and common side effects were fever and hypotension. Tumor lysis syndrome was seen in one patient [42-44]. Lack of previous chemotherapy conditioning and low dosage of CAR-T cells may account for the relatively low response rate. However, donor-derived CAR-T therapy is still a promising approach for treating R/R CLL because of the excellent state of donor $\mathrm{T}$ cells and graft versus leukemia effects, and someday "off-the-shelf" may be possible [45].

In the era of novel drugs, ibrutinib, a Bruton's tyrosine kinase (BTK) inhibitor, is the first choice for first-line and R/R therapy for CLL with 17 p deletion or TP53 mutation [46]. It remains unclear how to treat CLL patients after failure of ibrutinib. Turtle et al. [11] evaluated the feasibility of using CAR-T therapy for CLL patients who were refractory to ibrutinib. It was a dose escalation trial, and a total of 24 patients, most of whom had a complex karyotype or $17 \mathrm{p}$ deletion, received lymphodepleting conditioning followed by infusion of $2 \times 10^{5}, 2 \times 10^{6}$, or $2 \times 10^{7}$ CAR-T cells $/ \mathrm{kg}$. The overall response rate was $71 \%$ at 4 weeks. The percentage of patients who were absent of marrow disease detected by flow cytometry and absent of marrow malignant immunoglobulin heavy chain $(I G H)$ clone detected by deep IGH sequencing was $88 \%$ and $58 \%$, respectively. However, the incidence of CRS and neurotoxicity was $83 \%$ and $33 \%$, respectively, which was higher than that in previous reports. The number of grades 1-2 CRS, grade 4 CRS, and grade 5 CRS were 18,1 , and 1 , respectively. The number of grades $1-2$, grade 3 , and grade 5 neurotoxicity were 2,5 , and 1 , respectively. Neurotoxicity was reversible, and it was always associated with CRS. In total, six patients needed tocilizumab or glucocorticoid for CRS, and two patients needed ICU treatment for neurotoxicity. Positron emission tomography-computed tomography (PET-CT) was useful for lymph node response evaluation in CAR-T therapy. Some CLL patients classified as 
Table 2 The outcomes of CAR-T therapy with different costimulatory molecules for CLL patients in published trials

\begin{tabular}{|c|c|c|c|c|c|c|c|}
\hline Signal & Target & Study & Number & Preconditioning & Source & Cell dose & ORR and CRR \\
\hline \multirow[t]{15}{*}{ CD28 } & \multirow[t]{13}{*}{ CD19 } & \multirow[t]{3}{*}{ 2011.Brentjens } & \multirow[t]{3}{*}{8} & \multirow[t]{2}{*}{ None (3) } & \multirow{3}{*}{ Autologous } & \multirow{2}{*}{$\begin{array}{l}\text { Without preconditioning: } \\
1.2-3.0 \times 10^{7} / \mathrm{kg}\end{array}$} & ORR 1/7 (14.3\%) \\
\hline & & & & & & & CRR 0/7 (0\%) \\
\hline & & & & Cyclophosphamide (5) & & $\begin{array}{l}\text { With preconditioning: } \\
0.4-1.0 \times 10^{7} / \mathrm{kg}\end{array}$ & $\begin{array}{l}\text { One died before } \\
\text { evaluation }\end{array}$ \\
\hline & & \multirow[t]{2}{*}{ 2012.Kochenderfer } & \multirow[t]{2}{*}{4} & \multirow{2}{*}{$\begin{array}{l}\text { Fludarabine }+ \\
\text { cyclophosphamide (4) }\end{array}$} & \multirow[t]{2}{*}{ Autologous } & \multirow[t]{2}{*}{$0.3-2.8 \times 10^{7} / \mathrm{kg}$} & ORR 3/4 (75.0\%) \\
\hline & & & & & & & CRR 1/4 (25.0\%) \\
\hline & & \multirow[t]{2}{*}{ 2013.Cruz } & \multirow[t]{2}{*}{4} & \multirow[t]{2}{*}{ None } & \multirow[t]{2}{*}{ Allogeneic } & \multirow[t]{2}{*}{$1.5-12 \times 10^{7} / \mathrm{m}^{2}$} & ORR 1/4 (25.0\%) \\
\hline & & & & & & & CRR 0/4 (0\%) \\
\hline & & \multirow[t]{2}{*}{ 2015.Kochenderfer } & \multirow[t]{2}{*}{4} & \multirow{2}{*}{$\begin{array}{l}\text { Fludarabine }+ \\
\text { cyclophosphamide (4) }\end{array}$} & \multirow[t]{2}{*}{ Autologous } & \multirow[t]{2}{*}{$1-4 \times 10^{6} / \mathrm{kg}$} & ORR 4/4 (100\%) \\
\hline & & & & & & & CRR 3/4 (75.0\%) \\
\hline & & \multirow{2}{*}{$\begin{array}{l}\text { 2015.Kochenderfer } \\
\text { 2016.Brudno }\end{array}$} & \multirow[t]{2}{*}{5} & \multirow[t]{2}{*}{ None } & \multirow[t]{2}{*}{ Allogeneic } & \multirow[t]{2}{*}{$0.4-3.1 \times 10^{6} / \mathrm{kg}$} & ORR 2/5 (40.0\%) \\
\hline & & & & & & & CRR 1/5 (20.0\%) \\
\hline & & \multirow[t]{2}{*}{ 2018.Geyer } & \multirow[t]{2}{*}{8} & \multirow[t]{2}{*}{ Cyclophosphamide (8) } & \multirow[t]{2}{*}{ Autologous } & \multirow{2}{*}{$\begin{array}{l}3 \times 10^{6} / \mathrm{kg} \\
1 \times 10^{7} / \mathrm{kg} \\
3 \times 10^{7} / \mathrm{kg}\end{array}$} & ORR 2/8 (25.0\%) \\
\hline & & & & & & & CRR 2/8 (25.0\%) \\
\hline & \multirow[t]{2}{*}{ k } & \multirow[t]{2}{*}{ 2016. Ramos } & 2 & None & Autologous & $9.1 \times 10^{7} / \mathrm{m}^{2}$ & ORR 0/2 (0\%) \\
\hline & & & & & & $1.6 \times 10^{8} / \mathrm{m}^{2}$ & CRR 0/2 (0\%) \\
\hline CD137 & CD19 & 2011.Kalos & 14 & Bendamustine (6) & Autologous & $0.14-11 \times 10^{8}$ & ORR 8/14 (57.1\%) \\
\hline & & 2011.Porter & & Fludarabine/cyclophosphamide (3) & & & CRR 4/14 (28.6\%) \\
\hline & & 2015.Porter & & Pentostatin/cyclophosphamide (5) & & & \\
\hline & & 2017.Turtle & 24 & $\begin{array}{l}\text { Fludarabine + cyclophosphamide } \\
\text { (21) }\end{array}$ & Autologous & $\begin{array}{l}2 \times 10^{5} / \mathrm{kg} \\
2 \times 10^{6} / \mathrm{kg}\end{array}$ & ORR 16/23 (69.6\%) \\
\hline & & & & Fludarabine (2) & & & CRR 4/23 (17.4\%) \\
\hline & & & & Cyclophosphamide (1) & & $2 \times 10^{7} / \mathrm{kg}$ & $\begin{array}{l}\text { One died before } \\
\text { evaluation }\end{array}$ \\
\hline
\end{tabular}

PR by the International Workshop on Chronic Lymphocytic Leukemia (IWCLL) were restaged as CR after PET-CT scan due to no lesions with fluorodeoxyglucose uptake. Despite low infusion dose, the overall response rate acquired in ibrutinib-resistant patients were satisfactory comparing with results reported by Brentjens et al. [32] in 2011. In Brentjens et al. study, all patients had bulky lymphadenopathy, and did not receive preconditioning or only got cyclophosphamide. The mean CD4/ CD8 ratio in cellular products was 10.5, which was much higher than 1 , the ideal ratio for CAR-T therapy [47]. The persistence time and the ability of cytokine release of CAR-T cells were inferior to those in Turtle's research, which might be due to the relatively low level of manufacturing technique of CAR-T cells in 2011. Besides, ibrutinib could improve $\mathrm{T}$ cell function in CLL patients, and eventually, enhance the efficacy of CAR-T therapy. In summary, CAR-T therapy is a good choice for patients after failure of ibrutinib. It is worth mentioning that control of adverse events and application of PET-CT are vital in this process.

Additionally, combining ibrutinib with anti-CD19 CAR-T was a promising idea to treat heavily pretreated
CLL individuals or untreated CLL patients with TP53 disruption. A total of $10 \mathrm{CLL}$ patients were enrolled in a pilot trial and none of them achieved CR when treated with ibrutinib. They were lymphodepleted before CAR-T infusion and continued to take ibrutinib. At 3 months, $89 \%$ of evaluable patients achieved a minimal residual disease (MRD)-negative marrow CR. CRS was seen in nine patients, but tocilizumab was not required. Compared with single ibrutinib or CAR-T, combination therapy had a better outcome and controllable toxicity, and therefore, ibrutinib and CAR-T had a synergistic effect to treat high-risk CLL patients, especially those with TP53 disruption [48].

Using CAR-T cells as a consolidative therapy was a novel concept presented by Geyer and his colleagues [49]. Totally eight patients who had residual CLL cells after pentostatin, cyclophosphamide, and rituximab treatment were enrolled in this clinical trial. All patients had poor prognostic factors such as unmutated immunoglobulin heavy chain variable region gene. Patients received low-dose chemotherapy with $600 \mathrm{mg} / \mathrm{m}^{2}$ cyclophosphamide, followed by infusion of $3 \times 10^{6}, 1 \times 10^{7}$,

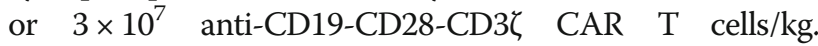


Eventually, two patients achieved CR, and no severe CRS and neurotoxicity were seen after CAR-T cells infusion. Persistence time of CAR-T cells was relatively short in these CLL patients, with the longest time was 48 days after infusion.

\section{CD23}

CD23 (FcepsilonRII), a low-affinity IgE receptor, is involved in IgE synthesis. The typical phenotype of CLL cells is $\mathrm{CD} 5^{+} \mathrm{CD} 23^{+}$, which makes $\mathrm{CD} 23$ a potential target for CLL therapy. The feasibility and safety of anti-CD23 CAR-T cells were tested in a recent study [50]. Notably, the results showed that in vitro, CAR-T cells could effectively lyse either CLL-like MEC-1 cells or primary CLL cells and release cytokines such as interferon- $\gamma$ (IFN- $\gamma)$ without serious toxicity for normal B cells. Additionally, anti-CD23 CAR-T cells can slow the proliferation of tumor cells in a CLL xenograft mouse model. Therefore, preclinical results showed that anti-CD23 CAR-T cells could eliminate CLL cells effectively in vitro and in vivo. Similar to the sequential infusion of anti-CD19 and anti-CD22 CAR-T cells in treating $R / R$ acute lymphocytic leukemia (ALL) as well as $B$ cell lymphoma, and combined infusion of CD19 and $\mathrm{B}$ cell mature antigen (BCMA)-specific CAR-T cells for $\mathrm{R} / \mathrm{R}$ multiple myeloma, combining anti-CD19 with anti-CD23 CAR-T cells to treat R/R CLL might be a promising strategy as well.

\section{ROR1}

Tyrosine kinase-like orphan receptor 1 (ROR1), also known as neurotrophic tyrosine kinase, receptor-related 1 , is a member of the receptor tyrosine kinase-like orphan receptor family. ROR1 is highly expressed on CLL cells, but not on normal B cells, which makes ROR1 an ideal tumor-specific antigen for antitumor immunotherapy [51]. Preclinical data demonstrated that CAR-T cells can accurately recognize autologous ROR1-expressing tumor cells or cell lines and could serve as a powerful weapon to eliminate chemotherapy resistant CLL cells. However, it should be noted that on-target/off-tumor toxicity must be taken into consideration when using anti-ROR1 CAR-T because of its expression on other normal tissues, such as parathyroid, pancreatic islet cells, and gastrointestinal tract [52-55].

\section{$\kappa$ light chain}

CLL cells are originated from monoclonal B lymphocytes and restrictively express $\mathrm{K}$ or $\lambda$ light chain. Unlike CD19, CAR-T cells targeting $\mathrm{k}$ or $\lambda$ chain can only kill a fraction of normal $B$ cells, which may alleviate the adverse effect of B cell aplasia. A phase 1 dose escalation clinical trial, in which two $\mathrm{K}^{+} \mathrm{R} / \mathrm{R}$ CLL patients were involved, was designed to evaluate the role of anti-k CAR-T cells in hematologic malignancies. Neither of them received lymphodepleting conditionings. One patient exhibited no response after infusion with $9.1 \times 10^{7} / \mathrm{m}^{2}$ CAR-T cells once, and the other, who was infused with $1.6 \times 10^{8} / \mathrm{m}^{2}$ CAR-T cells twice, eventually showed stable disease lasting 6 weeks. No serious adverse events were seen in these two patients. Low infusion dosage, low expression of $\kappa$ on the surface of CLL cells, and no lymphodepleting conditionings may explain these unsatisfactory results and the feasibility of anti-k CAR-T cells in CLL needs further validation [56].

\section{CD20}

CD20 is a mature B cell antigen limitedly existing on the surface of CLL cells. Nowadays, many novel immunotherapy drugs targeting CD20, such as rituximab, ofatumumab, and GA101, can exert their function to kill CLL cells by antibody-dependent cell-mediated cytotoxicity (ADCC) or complement-dependent cytotoxicity. However, CLL cells may be gradually refractory to these drugs after a few days of therapy by downregulating the expression of CD20. A recent study showed that CLL cells, which were resistant to $\mathrm{CD} 20$ monoclonal antibodies, could be lysed by anti-CD20 CAR-T cells. Further study demonstrated that the threshold density of CD20 was nearly 200 molecules per cell for CAR-T lysis activity and several thousand for CAR-T cytokine release [57]. Therefore, if we can choose a target whose density on CLL cells is between the threshold of lysis activity and cytokine release, the incidence of CRS may greatly decrease.

\section{FcuR}

Immunoglobulin $M$ Fc receptor $\left(\mathrm{F}_{\mathrm{C}} \mu \mathrm{R}\right)$, also known as the Fas apoptotic inhibitory molecule-3 or TOSO, is selectively expressed on CLL cells and limitedly expressed by normal B cells. Faitschuk et al. [58] confirmed that anti-Fc $\mu R$ CAR-T cells, derived from CLL patients with different disease status, could effectively kill CLL cells in vitro and in vivo by releasing a variety of factors, but not kill normal cells, thus avoiding off-target effect to a certain degree. Preclinical data reveals that $\mathrm{Fc} \mu \mathrm{R}$ is superior to previous target antigens such as CD19 and CD23 and has the potential to have a place in CLL immunotherapy.

\section{CD16 V158}

All of the CAR-T cells mentioned previously directly kill tumor cells. It is known to all that natural killer cells, which have a CD16 V158 variant, can exert ADCC by binding to the Fc fragment of immunoglobulin. Based on it, Kudo et al. [59] designed a kind of CAR-T cells containing CD16 V158 scFv so that they could eliminate CLL cells effectively by the regulation of rituximab at a 
small count. Besides, rituximab combined with anti-CD16 V158 CAR-T cells showed a better capacity to kill CLL cells than rituximab only. In all, anti-CD16 V158 CAR-T cells can enhance the efficacy of rituximab and have the potential to be a universal approach in the future.

\section{Adverse events}

CRS, B cell aplasia, neurotoxicity, and infection are common adverse events of CAR-T cell therapy in CLL [60-62]. When encountering target cells, CAR-T cells are activated in a short time and release many kinds of cytokines such as interleukin (IL)-6, IL-10, tumor necrosis factor (TNF)- $\alpha$, and IFN- $\gamma$ at high-levels. In addition, macrophages, monocytes, natural killer cells, and dendritic cells can also be involved in the inflammatory response by producing inflammatory factors under the stimulation of CAR-T cells, target cells, and inflammatory mediators [63]. Recent studies showed that monocytes/macrophages were the major sources of IL-1 and IL-6 during CRS [64, 65]. The severity of CRS is positively associated with high bone marrow tumor burden, thrombocytopenia before preconditioning, number of CAR-T cells, and so on [61]. The incidence of CRS is relatively high in CLL (CRS occurs in nearly 83\% CLL patients), especially for patients who used ibrutinib previously, which may be due to the recovery of $\mathrm{T}$ cell exhaustion [11]. CRS can affect multiple organ systems, and clinical symptoms of CRS in CLL are various, ranging from fever and hypoxia to renal failure and even death [34]. IL-6 receptor antagonist tocilizumab and corticosteroids are two desirable regimens which are often used to attenuate symptoms when necessary [66]. Tocilizumab is used with the dose of 4 to $8 \mathrm{mg} / \mathrm{kg}$ (not to exceed $800 \mathrm{mg}$ ) and infused over $1 \mathrm{~h}$. When CRS is refractory to tocilizumab, methylprednisolone can be used with the dose of $1-2 \mathrm{mg} / \mathrm{kg}$ every $12 \mathrm{~h}$. In addition, dexamethasone can be used with the dose of $10 \mathrm{mg}$ every $6 \mathrm{~h}$. All these drugs are used according to different clinical symptoms [67]. Because CD19 is widely expressed on B cells, anti-CD19 CAR-T cells can both eliminate CLL cells and normal B cells, causing B cell aplasia, which is characterized by the deficiency of $\mathrm{B}$ cells and immunoglobulin [33]. When it occurs, extra-immunoglobulin infusion is a feasible solution in order to refrain from infection [12]. In the past 5 years, neurologic toxicity, whose mechanism remains unclear, has been reported in a few CLL patients and clinicians are gradually aware of this issue. The incidences of grades 1-3 neurotoxicity and grades 4-5 neurotoxicity in CLL are $29 \%$ and $4 \%$ respectively [62]. Typically, its symptoms include delirium, aphasia, seizure, etc. Time of first fever after the CAR-T cell infusion is negatively correlated with the severity of neurotoxicity. Luckily, most neurologic toxicity is reversible and can recover spontaneously without further treatment. At present, CAR-T-cell-therapy-associated toxicity 10-point neurological assessment score is recommended to test encephalopathy syndrome of patients. When neurologic toxicity is severe, high-dose corticosteroids are recommended to use. Additionally, anti-IL-6 therapy such as tocilizumab or siltuiximab can be used if neurologic toxicity is associated with concurrent CRS [68]. Peak level of CAR-T cells in blood is positively associated with efficacy and toxicity in CLL. When the number of peak $\mathrm{CD}^{+}$and CD4 ${ }^{+}$CAR-T cells approximately reach to $100 / \mu l$ and $30 / \mu \mathrm{l}$, respectively, the estimated probability of marrow MRD-negative CR, grade $\geq 2$ CRS and grade $\geq 3$ neurotoxicity are $95 \%, 60 \%$ and $30 \%$, respectively [61]. Infection is a severe toxicity after CAR-T treatment because of hypogammaglobulinemia and neutropenia, sometimes even causing death. The incidence of grade $\geq 3$ infection in CLL is $21 \%-25 \%$ according to previous reports and is significantly lower than ALL. Bacteria are the most common causes, and viruses as well as fungi are also involved in it [60]. Top-level antibiotics, antifungal agents, and antiviral agents are indispensable when infection occurs. According to the latest data of ALL, CLL, and lymphoma, among events with specific pathogens, all bacterial infections were opportunistic infections, including coagulase-negative Staphylococcus aureus (4/11), Streptococcus (2/11), Enterococcus faecium (1/11), Escherichia coli (1/11), Acinetobacter ursingii (1/11), Stenotrophomonas maltophilia (1/11), and Capnocytophoga sputigena (1/11). Mycoplasma hominis was also reported in one patient. Opportunistic infections of viruses included cytomegalovirus (1/13) and Epstein-Barr virus (2/ $13)$, and fungal infections included candida (4/5) and Aspergillus ustus (1/5). Prior anti-tumor treatment regimens $\geq 4$, high dose of CAR-T cells, ANC $<500$ cells/ $\mu \mathrm{l}$ on the day of infection and high grade of CRS/neurotoxicity were high-risk factors of infection [60].

\section{Advances in efficacy}

CAR-T cells can effectively eliminate CLL cells, however, not all R/R CLL patients can benefit from this treatment. Previous clinical trials revealed that the overall response rate was $53 \%$ [69], but only $26 \%$ of individuals could achieve sustained remission [70]. As a consequence, finding feasible biomarkers to predict efficacy and exploring valid strategies to improve functions of CAR-T cells are essential in order to take full advantage of this weapon.

Fraietta et al. [70] retrospectively analyzed $41 \mathrm{R} / \mathrm{R}$ CLL patients who received CAR-T cell therapy, and by comparing the different characteristics of effective group and invalid group, they found that efficacy of CAR-T cells was determined by intrinsic potency, memory-related 
gene expression, subpopulation, cytokines, and so on, while it was not associated with age, previous treatment, tumor burden, or TP53 states. After infusion, the number of CAR-T cells in peripheral blood would immediately decline to a low level because of redistribution in peripheral blood, bone marrow, and other tissues, and then undergo rapid expansion. During the process of manufacture and infusion, CAR-T cells derived from CR patients showed superior capacity of expansion and persistence than nonresponding (NR) patients, which was reflected in the higher peak level and the longer half-life, but time to peak level was no different between two groups [69]. These demonstrated that high peak absolute number of CAR-T cells, favorable reactivity to target cells, and persistent existence were indispensable in guaranteeing efficacy. Transcriptomic profiles showed that CAR-T cells from CR patients were enriched in early memory-associated genes while $\mathrm{T}$ cells from NR patients showed upregulated expression of late memory, effector, apoptosis, or aerobic glycolysis-related genes. Regarding cell types, the frequency of $\mathrm{CD} 8^{+} \mathrm{T}$ memory stem cells $\left(T_{\mathrm{SCM}}\right)$ and $\mathrm{CD}_{2} 7^{+} \mathrm{CD} 45 \mathrm{RO}^{-} \mathrm{CD} 8^{+} \mathrm{T}$ cells were higher in CR patients than in NR patients. The differentiation of $\mathrm{T}$ cells is from early memory to effector memory stage, and metabolism changes from anabolism to catabolism. The differences of transcriptomic profiles and cell types of CAR-T cells between $C R$ and NR patients suggested that CAR-T cells from CR patients are in early stage of differentiation and have strong proliferative ability and long-term survival, while CAR-T cells from NR patients are in terminal stage and have reasonable but unsustainable effector function [71]. Additionally, infusing $\mathrm{CD} 27^{+} \mathrm{PD}-1^{-} \mathrm{CD} 8^{+} \mathrm{CAR}-\mathrm{T}$ cells is essential in order to achieve favorable efficacy because $\mathrm{CD} 27^{+} \mathrm{PD}-1^{-} \mathrm{CD} 8^{+}$CAR-T cells had high expression of IL- 6 receptor- $\beta$ chain and when stimulated by IL- 6 , levels of phosphorylated signal transducer and activator of transcription 3 (STAT3) rose and CAR-T cells quickly expanded. No significant difference was seen in the subset of $\mathrm{CD}^{+} \mathrm{T}$ cells between $\mathrm{CR}$ and NR patients. Moreover, concentrations of serum IL-15 and IL- 6 were higher in CR patients than in NR patients, which are useful for CAR-T cells' proliferation.

Early immune deficiency is a hallmark of CLL patients, and the prominent feature is $\mathrm{T}$-cell exhaustion. Under the stimulation of a large number of malignant B cells like chronic viral infections, $\mathrm{T}$ cells gradually lose vigor and vitality [72]. In addition, drugs like fludarabine can also have an immunosuppressive impact on T cells, especially for $\mathrm{CD}^{+} \mathrm{T}$ cells. Compared with healthy persons, the expression of exhaustion markers, such as PD-1, CD160, and CD244, is upregulated on the surface of T cells from CLL patients. Besides, CD8 ${ }^{+} \mathrm{T}$ cells also show impaired function of proliferation, cytotoxicity, and cytolysis, while the ability of cytokine release is normal [73]. Moreover, CAR-T cells derived from $\mathrm{CD}^{+}$naïve $\mathrm{T}$ cells $\left(\mathrm{T}_{\mathrm{N}}\right)$ cells of CLL patients show the inferior ability of expansion and express a higher level of PD-1 than healthy individuals [72]. On this occasion, CAR-T cells derived from CLL patients are unable to expand and kill neoplasms normally. Consecutive ibrutinib treatment for more than 20 weeks can augment CAR-T cells' ability in the aspects of proliferation, persistence, and cytotoxicity in vitro and in vivo, while also promote the reconstitution of cellular immune by reducing the expression of immunosuppressive molecule PD- 1 on $\mathrm{CD} 8^{+} \mathrm{T}$ cells and CD200 on B-CLL cells, increasing the IFN- $\gamma$ secretion of $\mathrm{CD}^{+} \mathrm{T}$ cells, inhibiting IL-2 inducible T-cell kinase in $\mathrm{CD}^{+}{ }^{+} \mathrm{T}$ cells, driving $\mathrm{CD} 4^{+} \mathrm{T}$ cells to develop into $\mathrm{T}$ helper 1-type, and increasing $\mathrm{T}$ cell repertoire diversity $[74,75]$. Results of combining CAR-T cells with ibrutinib in CLL xenograft models were consistent with those in the clinical trials [48].

According to the different differentiation states, cell surface molecules and functions, $\mathrm{T}$ cells are mainly divided into four subgroups: $T_{\mathrm{N}}$, effector memory $\mathrm{T}$ cells $\left(T_{\mathrm{EM}}\right)$, central memory $\mathrm{T}$ cells $\left(T_{\mathrm{CM}}\right)$, and $\mathrm{T}$ effector cells ( $\left.T_{\mathrm{E}}\right)$ [71]. Previous studies demonstrated that in CLL treated with either $\mathrm{CD}^{+}$or $\mathrm{CD} 8^{+}$CAR-T cells, $\mathrm{T}_{\mathrm{N}}$, and $\mathrm{T}_{\mathrm{CM}}$ were superior to $T_{\mathrm{EM}}$ and $T_{\mathrm{E}}$ in anti-tumor activity, and they showed great abilities of proliferation and cytotoxicity. Unfortunately, CAR-T cellular products of CLL patients always exhibit low $T_{\mathrm{N}} / T_{\mathrm{E}}$ ratio and thus can only exert limited function in subsequent therapy. IL-7/ IL-15 can induce CAR-T cells to differentiate into $T_{\mathrm{N}}$, $T_{\mathrm{SCM}}$, while CAR-T cells stimulated by IL- 2 are susceptible to become $T_{\mathrm{EM}}$ and regulatory $\mathrm{T}$ cells. Therefore, it is a good choice to use IL-7/IL-15 as stimulants in the process of manufacture [72]. In addition, cooperativity is seen when using $T_{\mathrm{N}}$ and $T_{\mathrm{CM}}$ at the same time, and a defined ratio of $\mathrm{CD} 4 / \mathrm{CD} 8$ such as 1:1 lead to better outcomes $[47,76]$. Unfortunately, the CD4/CD8 T cells ratio of heavily pretreated CLL patients is far from 1:1 and the subsets are mainly $T_{\mathrm{EM}}$ and $T_{\mathrm{E}}$. Therefore, reallocating CD4/CD8 ratio and choosing $T_{\mathrm{N}}$ and $T_{\mathrm{CM}}$ by sorting $\mathrm{T}$ cells according to different phenotype are desirable methods to enhance CAR-T efficacy in CLL.

TET2 can control the proliferation of blood cells by regulating their formation. A recent study demonstrated that in a CLL patient who received CAR-T therapy, the structure of TET2 was disrupted when CAR lentivirus inserted into it, and consequently, CAR-T cells could proliferate capriciously without the inhibition of TET2. In this condition, more than $90 \%$ of CAR-T cells in this patient's body have the same $\mathrm{T}$ cell receptor beta repertoire, which means they are from the same cell. What is more, $\mathrm{CD} 8^{+}$CAR-T cells with disrupted TET2 tend to differentiate into $T_{\mathrm{CM}}$, characterized as early memory, 
rather than $T_{\mathrm{E}}$, so that they can last for a long time, and patients can maintain $\mathrm{CR}$ status. However, these changes may result in uncontrollable proliferation of CAR-T cells, which could generate another form of leukemia and eventually do more harm than good to CLL patients. To solve this problem, adding suicide genes or CD20 antigen into TET2 disrupted CAR-T cells should be taken into consideration in order to ensure the safety of patients [77].

\section{Conclusions}

In the last 2 years, enormous progress was witnessed in the aspect of CAR-T therapy for CLL. However, no comprehensive review had been reported so far. This review summarizes the development of CAR-T therapy in CLL and is intended to raise physicians' awareness of cellular therapy. Nowadays, CAR-T therapy, a promising adoptive $\mathrm{T}$ cell immunotherapy, has become more and more important in the treatment of CLL. As an incurable disease, CLL will relapse after a few years. For patients with adverse prognostic features, such as TP53 disruption and unmutated immunoglobulin heavy chain variable region, their diseases will either relapse in a short time or can be resistant to traditional immunochemotherapy. Even in the era of novel drugs, drug resistance will occur in some patients. CAR-T therapy can effectively eradicate CLL cells in $R / R$ patients, even for those resistant to ibrutinib. At present, CAR-T therapy and stem cell transplantation are recommended as ultimate weapons for R/R CLL patients [78]. In general, the overall response rate is $53 \%$ [69], but only $26 \%$ of individuals can achieve sustained remission [70]. Preconditioning is necessary before infusion of CAR-T cells, and adverse events are manageable with current infusion dose. Because of the heterogeneity of these clinical trials, no significant difference is seen between co-stimulatory molecule CD28 and CD137. In general, the ALL patients are younger than CLL patients. Besides, the microenvironment of CLL inhibits the activation and proliferation of $\mathrm{T}$ cells. These two reasons account for the inferior efficacy of CAR-T therapy for CLL than that for ALL $[79,80]$. Certainly, many problems need to be solved in CAR-T therapy for CLL. For example, which antigen to choose, how to alleviate adverse events, and how to enhance efficacy. Furthermore, $\mathrm{T}$ cell senescence and CAR-T cell exhaustion receive more and more attention [81]. To some extent, these problems limit the application of CAR-T therapy in CLL. In the future, combination with new drugs such as ibrutinib, venetoclax, and idelalisib, and sequential infusion of CAR-T cells targeting multiple antigens like $\mathrm{CD} 19, \mathrm{CD} 23$, and $\mathrm{F} c \mu \mathrm{R}$ may be the trend of CAR-T therapy for CLL. Furthermore, researchers should try their best to formulate suitable projects to treat CLL patients with CAR-T therapy, so that eventually, patients can benefit from this weapon.

\section{Abbreviations}

ADCC: Antibody-dependent cell-mediated cytotoxicity; ALL: Acute lymphocytic leukemia; BCMA: B cell mature antigen; BTK: Bruton's tyrosine kinase; CAR: Chimeric antigen receptor; CAR-T: Chimeric antigen receptorengineered T cells; CCR: Chimeric co-stimulatory receptor; CLL: Chronic lymphocytic leukemia; CR: Complete remission; CRS: Cytokine release syndrome; CTLA-4: Cytotoxic T-lymphocyte-associated protein 4; Fc $\mathrm{R}$ : Immunoglobulin M Fc receptor; iCAR: Inhibitory chimeric antigen receptor; ICU: Intensive care unit; IFN- $\gamma$ : Interferon- $\gamma$; Ig: Immunoglobulin; IGH: Immunoglobulin heavy chain; IL: Interleukin; IWCLL: International Workshop on Chronic Lymphocytic Leukemia; MRD: Minimal residual disease; NR: Nonresponding; PD: Progressive disease; PD-1: Programmed cell death protein 1; PET-CT: Positron emission tomography-computed tomography; PR: Partial remission; R/R: Relapsed and refractory; ROR1: Tyrosine kinase-like orphan receptor 1; scFv: Single-chain antibody fragment; SD: Stable disease; STAT3: Signal transducer and activator of transcription 3; $T_{\mathrm{CM}}$ : Central memory $T$ cells; $T_{\mathrm{E}}$ : $T$ effector cells; $T_{\mathrm{EM}}$ : Effector memory $T$ cells; $T_{\mathrm{N}}$ : Naïve $T$ cells; TNF: Tumor necrosis factor; TP53: Tumor protein 53; $T_{\text {SCM: }}$ T memory stem cells

\section{Acknowledgements}

Not applicable

\section{Funding}

This study was supported by National Natural Science Foundation of China (81720108002), Jiangsu Province's Medical Elite Programme (ZDRCA2016022), Project of National Key Clinical Specialty, Jiangsu Provincial Special Program of Medical Science (BL2014086 and BE2017751) and National Science and Technology Major Project (2018ZX09734007).

\section{Availability of data and materials}

Data sharing is not applicable to this article as no datasets were generated or analyzed during the current study.

\section{Authors' contributions}

YZ wrote the initial drafts. WX and JL revised the review and finalized the last version of the article. All authors checked and approved the final version.

Ethics approval and consent to participate

Not applicable

\section{Consent for publication}

Not applicable

\section{Competing interests}

The authors declare that they have no competing interests.

\section{Publisher's Note}

Springer Nature remains neutral with regard to jurisdictional claims in published maps and institutional affiliations.

\section{Author details \\ ${ }^{1}$ Department of Hematology, The First Affiliated Hospital of Nanjing Medical University, Jiangsu Province Hospital, Nanjing 210029, China. ${ }^{2}$ Key Laboratory of Hematology of Nanjing Medical University, Nanjing 210029, China. \\ ${ }^{3}$ Collaborative Innovation Center for Cancer Personalized Medicine, Nanjing 210029, China.}

Received: 21 October 2018 Accepted: 8 November 2018

Published online: 20 November 2018

\section{References}

1. Fernandez-Martinez JL, deAndres-Galiana EJ, Sonis ST. Genomic data integration in chronic lymphocytic leukemia. J Gene Med. 2017;19(1-2):e2936.

2. Kim JA, Hwang B, Park SN, Huh S, Im K, Choi S, Chung HY, Huh J, Seo EJ, Lee JH, Bang D, Lee DS. Genomic profile of chronic lymphocytic leukemia in Korea identified by targeted sequencing. PLoS One. 2016;11(12):e0167641. 
3. DeSantis CE, Lin CC, Mariotto AB, Siegel RL, Stein KD, Kramer JL, Alteri R, Robbins AS, Jemal A. Cancer treatment and survivorship statistics, 2014. CA Cancer J Clin. 2014;64(4):252-71.

4. Yu S, Li A, Liu Q, Li T, Yuan X, Han X, Wu K. Chimeric antigen receptor T cells: a novel therapy for solid tumors. J Hematol Oncol. 2017;10(1):78.

5. Zhang $E, X u H . A$ new insight in chimeric antigen receptor-engineered $T$ cells for cancer immunotherapy. J Hematol Oncol. 2017;10(1):1.

6. Lorentzen CL, Straten PT. CD19-chimeric antigen receptor T cells for treatment of chronic lymphocytic leukaemia and acute lymphoblastic leukaemia. Scand J Immunol. 2015;82(4):307-19.

7. Almasbak H, Walseng E, Kristian A, Myhre MR, Suso EM, Munthe LA, Andersen JT, Wang MY, Kvalheim G, Gaudernack G, Kyte JA. Inclusion of an lgG1-fc spacer abrogates efficacy of CD19 CAR T cells in a xenograft mouse model. Gene Ther. 2015;22(5):391-403.

8. Hudecek M, Sommermeyer D, Kosasih PL, Silva-Benedict A, Liu L, Rader C, Jensen MC, Riddell SR. The nonsignaling extracellular spacer domain of chimeric antigen receptors is decisive for in vivo antitumor activity. Cancer Immunol Res. 2015;3(2):125-35.

9. Jonnalagadda M, Mardiros A, Urak R, Wang X, Hoffman L, Bernanke A Chang WC, Bretzlaff W, Starr R, Priceman S, Ostberg JR, Forman SJ, Brown CE. Chimeric antigen receptors with mutated lgG4 fc spacer avoid fc receptor binding and improve $T$ cell persistence and antitumor efficacy. Mol Ther. 2015;23(4):757-68.

10. Porter DL, Hwang WT, Frey NV, Lacey SF, Shaw PA, Loren AW, Bagg A, Marcucci KT, Shen A, Gonzalez V, Ambrose D, Grupp SA, Chew A, Zheng Z, Milone MC, Levine BL, Melenhorst JJ, June CH. Chimeric antigen receptor $\mathrm{T}$ cells persist and induce sustained remissions in relapsed refractory chronic lymphocytic leukemia. Sci Transl Med. 2015;7(303):303ra139.

11. Turtle CJ, Hay KA, Hanafi LA, Li D, Cherian S, Chen X, Wood B, Lozanski A, Byrd JC, Heimfeld S, Riddell SR, Maloney DG. Durable molecular remissions in chronic lymphocytic leukemia treated with CD19-specific chimeric antigen receptor-modified T cells after failure of Ibrutinib. J Clin Oncol. 2017;35(26):3010-20

12. Maude SL, Frey N, Shaw PA, Aplenc R, Barrett DM, Bunin NJ, Chew A, Gonzalez VE, Zheng Z, Lacey SF, Mahnke YD, Melenhorst JJ, Rheingold SR, Shen A, Teachey DT, Levine BL, June CH, Porter DL, Grupp SA. Chimeric antigen receptor T cells for sustained remissions in leukemia. N Engl J Med. 2014;371(16):1507-17.

13. Savoldo B, Ramos CA, Liu E, Mims MP, Keating MJ, Carrum G, Kamble RT, Bollard CM, Gee AP, Mei Z, Liu H, Grilley B, Rooney CM, Heslop HE, Brenner MK, Dotti G. CD28 costimulation improves expansion and persistence of chimeric antigen receptor-modified T cells in lymphoma patients. J Clin Invest. 2011;121(5):1822-6.

14. Chmielewski M, Abken H. TRUCKs: the fourth generation of CARs. Expert Opin Biol Ther. 2015;15(8):1145-54.

15. Zhou X, Di Stasi A, Tey SK, Krance RA, Martinez C, Leung KS, Durett AG, Wu MF, Liu H, Leen AM, Savoldo B, Lin YF, Grilley BJ, Gee AP, Spencer DM, Rooney CM, Heslop HE, Brenner MK, Dotti G. Long-term outcome after haploidentical stem cell transplant and infusion of $T$ cells expressing the inducible caspase 9 safety transgene. Blood. 2014;123(25):3895-905.

16. Di Stasi A, Tey SK, Dotti G, Fujita Y, Kennedy-Nasser A, Martinez C, Straathof K, Liu E, Durett AG, Grilley B, Liu H, Cruz CR, Savoldo B, Gee AP, Schindler J, Krance RA, Heslop HE, Spencer DM, Rooney CM, Brenner MK. Inducible apoptosis as a safety switch for adoptive cell therapy. N Engl J Med. 2011;365(18):1673-83.

17. Sommermeyer D, Hill T, Shamah SM, Salter Al, Chen Y, Mohler KM, Riddell SR. Fully human CD19-specific chimeric antigen receptors for T-cell therapy. Leukemia. 2017:31(10):2191-9.

18. Ren J, Liu X, Fang C, Jiang S, June CH, Zhao Y. Multiplex genome editing to generate universal CAR T cells resistant to PD1 inhibition. Clin Cancer Res. 2017;23(9):2255-66.

19. Ren J, Zhang X, Liu X, Fang C, Jiang S, June CH, Zhao Y. A versatile system for rapid multiplex genome-edited CAR T cell generation. Oncotarget. 2017:8(10):17002-11.

20. Fedorov VD, Themeli M, Sadelain M. PD-1- and CTLA-4-based inhibitory chimeric antigen receptors (iCARs) divert off-target immunotherapy responses. Sci Transl Med. 2013;5(215):215ra172.

21. Sun J, Sadelain M. The quest for spatio-temporal control of CAR T cells. Cell Res. 2015;25(12):1281-2.
22. Kloss CC, Condomines M, Cartellieri M, Bachmann M, Sadelain M. Combinatorial antigen recognition with balanced signaling promotes selective tumor eradication by engineered T cells. Nat Biotechnol. 2013:31(1):71-5.

23. Martyniszyn A, Krahl AC, Andre MC, Hombach AA, Abken H. CD20-CD19 bispecific CAR T cells for the treatment of B-cell malignancies. Hum Gene Ther. 2017;28(12):1147-57.

24. Zhang E, Gu J, Xue J, Lin C, Liu C, Li M, Hao J, Setrerrahmane S, Chi X, Qi W, $\mathrm{Hu} \mathrm{J}, \mathrm{Xu} \mathrm{H}$. Accurate control of dual-receptor-engineered T cell activity through a bifunctional anti-angiogenic peptide. J Hematol Oncol. 2018;11(1):44.

25. Wilkie S, Picco G, Foster J, Davies DM, Julien S, Cooper L, Arif S, Mather SJ, Taylor-Papadimitriou J, Burchell JM, Maher J. Retargeting of human T cells to tumor-associated MUC1: the evolution of a chimeric antigen receptor. J Immunol. 2008;180(7):4901-9.

26. Dai H, Wang Y, Lu X, Han W. Chimeric antigen receptors modified T-cells for Cancer therapy. J Natl Cancer Inst. 2016;108(7). https://doi.org/10.1093/jnci/ djv439.

27. Gill S, Maus MV, Porter DL. Chimeric antigen receptor T cell therapy: 25years in the making. Blood Rev. 2016;30(3):157-67.

28. Maude S, Barrett DM. Current status of chimeric antigen receptor therapy for haematological malignancies. Br J Haematol. 2016;172(1):11-22.

29. Kochenderfer JN, Feldman SA, Zhao Y, Xu H, Black MA, Morgan RA, Wilson WH, Rosenberg SA. Construction and preclinical evaluation of an anti-CD19 chimeric antigen receptor. J Immunother. 2009;32(7):689-702.

30. Maude SL, Teachey DT, Porter DL, Grupp SA. CD19-targeted chimeric antigen receptor T-cell therapy for acute lymphoblastic leukemia. Blood. 2015;125(26):4017-23.

31. Ramos CA, Heslop HE, Brenner MK. CAR-T cell therapy for lymphoma. Annu Rev Med. 2016;67:165-83.

32. Brentjens RJ, Riviere I, Park JH, Davila ML, Wang X, Stefanski J, Taylor C, Yeh R, Bartido S, Borquez-Ojeda O, Olszewska M, Bernal Y, Pegram H, Przybylowski M, Hollyman D, Usachenko Y, Pirraglia D, Hosey J, Santos E, Halton E, Maslak P, Scheinberg D, Jurcic J, Heaney M, Heller G, Frattini M, Sadelain M. Safety and persistence of adoptively transferred autologous CD19-targeted T cells in patients with relapsed or chemotherapy refractory B-cell leukemias. Blood. 2011;118(18):4817-28.

33. Kochenderfer JN, Dudley ME, Feldman SA, Wilson WH, Spaner DE, Maric I, Stetler-Stevenson M, Phan GQ, Hughes MS, Sherry RM, Yang JC, Kammula US, Devillier L, Carpenter R, Nathan DA, Morgan RA, Laurencot C, Rosenberg SA. B-cell depletion and remissions of malignancy along with cytokineassociated toxicity in a clinical trial of anti-CD19 chimeric-antigen-receptortransduced T cells. Blood. 2012;119(12):2709-20.

34. Kochenderfer JN, Dudley ME, Kassim SH, Somerville RP, Carpenter RO, Stetler-Stevenson M, Yang JC, Phan GQ, Hughes MS, Sherry RM, Raffeld M, Feldman S, Lu L, Li YF, Ngo LT, Goy A, Feldman T, Spaner DE, Wang ML, Chen CC, Kranick SM, Nath A, Nathan DA, Morton KE, Toomey MA, Rosenberg SA. Chemotherapy-refractory diffuse large B-cell lymphoma and indolent B-cell malignancies can be effectively treated with autologous T cells expressing an anti-CD19 chimeric antigen receptor. J Clin Oncol. 2015:33(6):540-9.

35. Ding ZC, Huang L, Blazar BR, Yagita H, Mellor AL, Munn DH, Zhou G. Polyfunctional CD4(+) T cells are essential for eradicating advanced B-cell lymphoma after chemotherapy. Blood. 2012;120(11):2229-39.

36. Ding ZC, Zhou G. Cytotoxic chemotherapy and CD4+ effector T cells: an emerging alliance for durable antitumor effects. Clin Dev Immunol. 2012:2012:890178

37. Ding ZC, Lu X, Yu M, Lemos H, Huang L, Chandler P, Liu K, Walters M, Krasinski A, Mack M, Blazar BR, Mellor AL, Munn DH, Zhou G. Immunosuppressive myeloid cells induced by chemotherapy attenuate antitumor CD4+ T-cell responses through the PD-1-PD-L1 axis. Cancer Res. 2014;74(13):3441-53.

38. Zhao Z, Condomines M, van der Stegen SJC, Perna F, Kloss CC, Gunset G, Plotkin J, Sadelain M. Structural Design of Engineered Costimulation Determines Tumor Rejection Kinetics and Persistence of CAR T cells. Cancer Cell. 2015:28(4):415-28.

39. Salter Al, Ivey RG, Kennedy JJ, Voillet V, Rajan A, Alderman EJ, Voytovich UJ, Lin C, Sommermever D, Liu L, Whiteaker JR, Gottardo R, Paulovich AG, Riddell SR. Phosphoproteomic analysis of chimeric antigen receptor signaling reveals kinetic and quantitative differences that affect cell function. Sci Signal. 2018;11(544):eaat6753. 
40. Kalos M, Levine BL, Porter DL, Katz S, Grupp SA, Bagg A, June CH. T cells with chimeric antigen receptors have potent antitumor effects and can establish memory in patients with advanced leukemia. Sci Transl Med. 2011;3(95):95ra73.

41. Porter DL, Levine BL, Kalos M, Bagg A, June CH. Chimeric antigen receptormodified T cells in chronic lymphoid leukemia. N Engl J Med. 2011;365(8): 725-33.

42. Cruz CR, Micklethwaite KP, Savoldo B, Ramos CA, Lam S, Ku S, Diouf O, Liu E, Barrett AJ, Ito S, Shpall EJ, Krance RA, Kamble RT, Carrum G, Hosing CM, Gee AP, Mei Z, Grilley BJ, Heslop HE, Rooney CM, Brenner MK, Bollard CM, Dotti G. Infusion of donor-derived CD19-redirected virus-specific $T$ cells for B-cell malignancies relapsed after allogeneic stem cell transplant: a phase 1 study. Blood. 2013;122(17):2965-73.

43. Kochenderfer JN, Dudley ME, Carpenter RO, Kassim SH, Rose JJ, Telford WG, Hakim FT, Halverson DC, Fowler DH, Hardy NM, Mato AR, Hickstein DD, Gea-Banacloche JC, Pavletic SZ, Sportes C, Maric I, Feldman SA, Hansen BG, Wilder JS, Blacklock-Schuver B, Jena B, Bishop MR, Gress RE, Rosenberg SA. Donor-derived CD19-targeted T cells cause regression of malignancy persisting after allogeneic hematopoietic stem cell transplantation. Blood. 2013;122(25):4129-39.

44. Brudno JN, Somerville RP, Shi V, Rose JJ, Halverson DC, Fowler DH, GeaBanacloche JC, Pavletic SZ, Hickstein DD, Lu TL, Feldman SA, Iwamoto AT, Kurlander R, Maric I, Goy A, Hansen BG, Wilder JS, Blacklock-Schuver B, Hakim FT, Rosenberg SA, Gress RE, Kochenderfer JN. Allogeneic T cells that express an anti-CD19 chimeric antigen receptor induce remissions of B-cell malignancies that Progress after allogeneic hematopoietic stem-cell transplantation without causing graft-versus-host disease. J Clin Oncol. 2016;34(10):1112-21.

45. Poirot L, Philip B, Schiffer-Mannioui C, Le Clerre D, Chion-Sotinel I, Derniame S, Potrel P, Bas C, Lemaire L, Galetto R, Lebuhotel C, Eyquem J, Cheung GW, Duclert A, Gouble A, Arnould S, Peggs K, Pule M, Scharenberg AM, Smith J. Multiplex genome-edited T-cell manufacturing platform for "off-the-shelf" adoptive T-cell immunotherapies. Cancer Res. 2015;75(18):3853-64.

46. Younes A, Ansell S, Fowler N, Wilson W, de Vos S, Seymour J, Advani R, Forero A, Morschhauser F, Kersten MJ, Tobinai K, Zinzani PL, Zucca E, Abramson J, Vose J. The landscape of new drugs in lymphoma. Nat Rev Clin Oncol. 2017;14(6):335-46.

47. Turtle CJ, Hanafi LA, Berger C, Gooley TA, Cherian S, Hudecek M, Sommermeyer D, Melville K, Pender B, Budiarto TM, Robinson E, Steevens NN, Chaney C, Soma L, Chen X, Yeung C, Wood B, Li D, Cao J, Heimfeld S, Jensen MC, Riddell SR, Maloney DG. CD19 CAR-T cells of defined CD4+:CD8+ composition in adult B cell ALL patients. J Clin Invest. 2016;126(6):2123-38.

48. Molica S. Ibrutinib continues to influence the therapeutic landscape of chronic lymphocytic leukemia: new data presented at ASCO 2017. BMC Med. 2017;15(1):156.

49. Geyer MB, Riviere I, Senechal B, Wang X, Wang Y, Purdon TJ, Hsu M, Devlin SM, Halton E, Lamanna N, Rademaker J, Sadelain M, Brentjens RJ, Park $J$ H. Autologous CD19-targeted CAR T cells in patients with residual CLL following initial purine analog-based therapy. Mol Ther. 2018;26(8):1896-905.

50. Giordano Attianese GM, Marin V, Hoyos V, Savoldo B, Pizzitola I, Tettamanti S, Agostoni V, Parma M, Ponzoni M, Bertilaccio MT, Ghia P, Biondi A, Dotti G, Biagi $E$. In vitro and in vivo model of a novel immunotherapy approach for chronic lymphocytic leukemia by anti-CD23 chimeric antigen receptor. Blood. 2011;117(18):4736-45.

51. Berger C, Sommermeyer D, Hudecek M, Berger M, Balakrishnan A, Paszkiewicz PJ, Kosasih PL, Rader C, Riddell SR. Safety of targeting ROR1 in primates with chimeric antigen receptor-modified T cells. Cancer Immunol Res. 2015;3(2):206-16.

52. Hudecek M, Schmitt TM, Baskar S, Lupo-Stanghellini MT, Nishida T, Yamamoto TN, Bleakley M, Turtle CJ, Chang WC, Greisman HA, Wood B, Maloney DG, Jensen MC, Rader C, Riddell SR. The B-cell tumorassociated antigen ROR1 can be targeted with $T$ cells modified to express a ROR1-specific chimeric antigen receptor. Blood. 2010;116(22):4532-41.

53. Yang J, Baskar S, Kwong KY, Kennedy MG, Wiestner A, Rader C. Therapeutic potential and challenges of targeting receptor tyrosine kinase ROR1 with monoclonal antibodies in B-cell malignancies. PLoS One. 2011;6(6):e21018.
54. Hudecek M, Lupo-Stanghellini MT, Kosasih PL, Sommermeyer D, Jensen MC, Rader C, Riddell SR. Receptor affinity and extracellular domain modifications affect tumor recognition by ROR1-specific chimeric antigen receptor T cells. Clin Cancer Res. 2013;19(12):3153-64.

55. Balakrishnan A, Goodpaster T, Randolph-Habecker J, Hoffstrom BG, Jalikis FG, Koch LK, Berger C, Kosasih PL, Rajan A, Sommermeyer D, Porter PL, Riddell SR. Analysis of ROR1 protein expression in human cancer and normal tissues. Clin Cancer Res. 2017;23(12):3061-71.

56. Ramos CA, Savoldo B, Torrano V, Ballard B, Zhang H, Dakhova O, Liu E, Carrum G, Kamble RT, Gee AP, Mei Z, Wu MF, Liu H, Grilley B, Rooney CM, Brenner MK, Heslop HE, Dotti G. Clinical responses with T lymphocytes targeting malignancy-associated kappa light chains. J Clin Invest. 2016;126(7):2588-96.

57. Watanabe K, Terakura S, Martens AC, van Meerten T, Uchiyama S, Imai M, Sakemura R, Goto T, Hanajiri R, Imahashi N, Shimada K, Tomita A, Kiyoi H, Nishida T, Naoe T, Murata M. Target antigen density governs the efficacy of anti-CD20-CD28-CD3 zeta chimeric antigen receptor-modified effector CD8 + T cells. J Immunol. 2015;194(3):911-20.

58. Faitschuk E, Hombach AA, Frenzel LP, Wendtner CM, Abken H. Chimeric antigen receptor $T$ cells targeting fc mu receptor selectively eliminate CLL cells while sparing healthy B cells. Blood. 2016;128(13):1711-22.

59. Kudo K, Imai C, Lorenzini P, Kamiya T, Kono K, Davidoff AM, Chng WJ, Campana D. T lymphocytes expressing a CD16 signaling receptor exert antibody-dependent cancer cell killing. Cancer Res. 2014;74(1):93-103.

60. Hill JA, Li D, Hay KA, Green ML, Cherian S, Chen X, Riddell SR, Maloney DG, Boeckh M, Turtle CJ. Infectious complications of CD19-targeted chimeric antigen receptor-modified T-cell immunotherapy. Blood. 2018;131(1):121-30.

61. Hay KA, Hanafi LA, Li D, Gust J, Liles WC, Wurfel MM, Lopez JA, Chen J, Chung D, Harju-Baker S, Cherian S, Chen X, Riddell SR, Maloney DG, Turtle CJ. Kinetics and biomarkers of severe cytokine release syndrome after CD19 chimeric antigen receptor-modified T-cell therapy. Blood. 2017;130(21): 2295-306.

62. Gust J, Hay KA, Hanafi LA, Li D, Myerson D, Gonzalez-Cuyar LF, Yeung C, Liles WC, Wurfel M, Lopez JA, Chen J, Chung D, Harju-Baker S, Ozpolat T, Fink KR, Riddell SR, Maloney DG, Turtle CJ. Endothelial activation and blood-brain barrier disruption in neurotoxicity after adoptive immunotherapy with CD19 CAR-T cells. Cancer Discov. 2017;7(12):1404-19.

63. Lee DW, Gardner R, Porter DL, Louis CU, Ahmed N, Jensen M, Grupp SA, Mackall CL. Current concepts in the diagnosis and management of cytokine release syndrome. Blood. 2014;124(2):188-95.

64. Norelli M, Camisa B, Barbiera G, Falcone L, Purevdorj A, Genua M, Sanvito F, Ponzoni M, Doglioni C, Cristofori P, Traversari C, Bordignon C, Ciceri F, Ostuni R, Bonini C, Casucci M, Bondanza A. Monocyte-derived IL-1 and IL-6 are differentially required for cytokine-release syndrome and neurotoxicity due to CAR T cells. Nat Med. 2018;24(6):739-48.

65. Giavridis T, van der Stegen SJC, Eyquem J, Hamieh M, Piersigilli A, Sadelain M. CAR T cell-induced cytokine release syndrome is mediated by macrophages and abated by IL-1 blockade. Nat Med. 2018;24(6):731-8.

66. Davila ML, Riviere I, Wang X, Bartido S, Park J, Curran K, Chung SS, Stefanski J, Borquez-Ojeda O, Olszewska M, Qu J, Wasielewska T, He Q, Fink $M$, Shinglot $H$, Youssif $M$, Satter M, Wang $Y$, Hosey J, Quintanilla H, Halton E, Bernal Y, Bouhassira DC, Arcila ME, Gonen M, Roboz GJ, Maslak P, Douer D, Frattini MG, Giralt S, Sadelain M, Brentjens R. Efficacy and toxicity management of 19-28z CAR T cell therapy in B cell acute lymphoblastic leukemia. Sci Transl Med. 2014; 6(224):224ra25

67. Brudno JN, Kochenderfer JN. Toxicities of chimeric antigen receptor T cells: recognition and management. Blood. 2016;127(26):3321-30.

68. Neelapu SS, Tummala S, Kebriaei P, Wierda W, Gutierrez C, Locke FL, Komanduri KV, Lin Y, Jain N, Daver N, Westin J, Gulbis AM, Loghin ME, de Groot JF, Adkins S, Davis SE, Rezvani K, Hwu P, Shpall EJ. Chimeric antigen receptor T-cell therapy - assessment and management of toxicities. Nat Rev Clin Oncol. 2018;15(1):47-62.

69. Mueller KT, Maude SL, Porter DL, Frey N, Wood P, Han X, Waldron E, Chakraborty A, Awasthi R, Levine BL, Melenhorst JJ, Grupp SA, June CH, Lacey SF. Cellular kinetics of CTL019 in relapsed/refractory B-cell acute lymphoblastic leukemia and chronic lymphocytic leukemia. Blood. 2017; 130(21):2317-25. 
70. Fraietta JA, Lacey SF, Orlando EJ, Pruteanu-Malinici I, Gohil M, Lundh S, Boesteanu AC, Wang Y, O'Connor RS, Hwang WT, Pequignot E, Ambrose DE, Zhang C, Wilcox N, Bedoya F, Dorfmeier C, Chen F, Tian L, Parakandi H, Gupta M, Young RM, Johnson FB, Kulikovskaya I, Liu L, Xu J, Kassim SH, Davis MM, Levine BL, Frey NV, Siegel DL, Huang AC, Wherry EJ, Bitter H, Brogdon JL, Porter DL, June CH, Melenhorst JJ. Determinants of response and resistance to CD19 chimeric antigen receptor (CAR) T cell therapy of chronic lymphocytic leukemia. Nat Med. 2018;24(5):563-71.

71. Golubovskaya V, Wu L. Different subsets of T cells, memory, effector functions, and CAR-T immunotherapy. Cancers (Basel). 2016;8(3). https://doi.org/10.3390/cancers8030036.

72. Hoffmann JM, Schubert ML, Wang L, Huckelhoven A, Sellner L, Stock S, Schmitt A, Kleist C, Gern U, Loskog A, Wuchter P, Hofmann S, Ho AD, Muller-Tidow C, Dreger P, Schmitt M. Differences in expansion potential of naive chimeric antigen receptor $\mathrm{T}$ cells from healthy donors and untreated chronic lymphocytic leukemia patients. Front Immunol. 2017;8:1956.

73. Riches JC, Davies JK, McClanahan F, Fatah R, Iqbal S, Agrawal S, Ramsay AG, Gribben JG. T cells from CLL patients exhibit features of T-cell exhaustion but retain capacity for cytokine production. Blood. 2013;121(9):1612-21.

74. Fraietta JA, Beckwith KA, Patel PR, Ruella M, Zheng Z, Barrett DM, Lacey SF, Melenhorst JJ, McGettigan SE, Cook DR, Zhang C, Xu J, Do P, Hulitt J, Kudchodkar SB, Cogdill AP, Gill S, Porter DL, Woyach JA, Long M, Johnson AJ, Maddocks K, Muthusamy N, Levine BL, June CH, Byrd JC, Maus MV. Ibrutinib enhances chimeric antigen receptor T-cell engraftment and efficacy in leukemia. Blood. 2016;127(9):1117-27.

75. Yin Q, Sivina M, Robins H, Yusko E, Vignali M, O'Brien S, Keating MJ, Ferrajoli A, Estrov Z, Jain N, Wierda WG, Burger JA. Ibrutinib therapy increases T cell repertoire diversity in patients with chronic lymphocytic leukemia. J Immunol. 2017;198(4):1740-7.

76. Sommermeyer D, Hudecek M, Kosasih PL, Gogishvili T, Maloney DG, Turtle CJ, Riddell SR. Chimeric antigen receptor-modified T cells derived from defined CD8+ and CD4+ subsets confer superior antitumor reactivity in vivo. Leukemia. 2016;30(2):492-500.

77. Fraietta JA, Nobles CL, Sammons MA, Lundh S, Carty SA, Reich TJ, Cogdill AP, Morrissette JJD, DeNizio JE, Reddy S, Hwang Y, Gohil M, Kulikovskaya I, Nazimuddin F, Gupta M, Chen F, Everett JK, Alexander KA, Lin-Shiao E, Gee MH, Liu X, Young RM, Ambrose D, Wang Y, Xu J, Jordan MS, Marcucci KT, Levine BL, Garcia KC, Zhao Y, Kalos M, Porter DL, Kohli RM, Lacey SF, Berger SL, Bushman FD, June CH, Melenhorst JJ. Disruption of TET2 promotes the therapeutic efficacy of CD19-targeted T cells. Nature. 2018;558(7709):307-12.

78. Burger JA, O'Brien S. Evolution of CLL treatment-from chemoimmunotherapy to targeted and individualized therapy. Nat Rev Clin Oncol. 2018;15(8):510-27.

79. Liu J, Zhong JF, Zhang X, Zhang C. Allogeneic CD19-CAR-T cell infusion after allogeneic hematopoietic stem cell transplantation in B cell malignancies. J Hematol Oncol. 2017;10(1):35.

80. Zhang LN, Song Y, Liu D. CD19 CAR-T cell therapy for relapsed/refractory acute lymphoblastic leukemia: factors affecting toxicities and long-term efficacies. J Hematol Oncol. 2018;11(1):41.

81. Kasakovski D, Xu L, Li Y. T cell senescence and CAR-T cell exhaustion in hematological malignancies. J Hematol Oncol. 2018;11(1):91.

\section{Ready to submit your research? Choose BMC and benefit from:}

- fast, convenient online submission

- thorough peer review by experienced researchers in your field

- rapid publication on acceptance

- support for research data, including large and complex data types

- gold Open Access which fosters wider collaboration and increased citations

- maximum visibility for your research: over $100 \mathrm{M}$ website views per year

At BMC, research is always in progress.

Learn more biomedcentral.com/submissions 